\title{
On the Plasma TSH Values in Normal Subjects and Patients with Several Endocrine Disorders
}

\author{
Naohisa HIROSHIGE \\ Department of Internl Medicine, Sumitomo Hospital, Osaka, Japan. \\ Keisuke KANAO and Masayo INOUE \\ Radioisotope Laboratory, Sumitomo Hospital, Osaka, Japan.
}

\section{Masahiro SAKODA and Makoto OTSUKI}

Second Department of Internal Medicine, Kobe University School of Medicine, Kobe, Japan.

Resting plasma TSH values in normal subjects and patients with various endocrine disorders were estimated by radioimmunoassay with the double antibody technique, using Human Thyrotropin Research Standard A as a standard.

The following results were obtained:

1) The values in 36 normal adults (ranging from 16 to 38 in age) were distributed between undetectable $(<1.7 \mu \mathrm{U} / \mathrm{ml})$ and $3.6 \mu \mathrm{U} / \mathrm{ml}$, and two thirds of them were undetectable.

2) Values in 17 aged subjects (over 70 years old) ranged from $<1.7$ to $8.9 \mu \mathrm{U} / \mathrm{ml}$. Undetectable values were found only in 5 cases of them.

3) In most cases of 53 patients with untreated hyperthyroidism, TSH values were undetectable, but in 5 cases detectable. In a group of patients during antithyroid drug administration, in which relative high serum PBI levels $(>5.0 \mu \mathrm{g} / \mathrm{dl})$ were observed, the TSH values were also undetectable, except in a few cases. But, in another group $(\mathrm{PBI}<5.0 \mu \mathrm{g} / \mathrm{dl})$, about half the number of patients had detectable values.

4) Values in 21 patients with primary hypothyroidism ranged from $6.6 \mu \mathrm{U} / \mathrm{ml}$ to $1155 \mu \mathrm{U} / \mathrm{ml}$.

5) In 3 cases of pituitary chromophobe adenoma with secondary hypothyroidism, undetectable values were observed.

6) In other cases of pituitary chromophobe adenoma and craniophrayngioma the values were roughly normal, and the values in patients with acromegaly were also similar, but in patients with diabetes insipidus they were slightly elevated.

7) 8 patients with simple goiter had values ranging from $<1.7 \mu \mathrm{U} / \mathrm{ml}$ to $6.6 \mu \mathrm{U} / \mathrm{ml}$. Only 2 of them had undetectable values.

(See pp. 569 577) 


\section{健常人及び各種内分泌疾患々者の基礎状態に 於ける血中 TSH 值について}

$\begin{array}{ccccc}\begin{array}{c}\text { 住友病院内科 } \\ \text { 弘 }\end{array} & \text { 重 } & \text { 尚 } & \text { 久 } \\ \text { 住友病院 RI 室 } & & & \\ \text { 金 } & \text { 尾 } & \text { 啓 } & \text { 右 } \\ \text { 井 } & \text { 上 } & \text { 雅 } & \text { 代 } \\ \text { 神戸大学第二内科学教室 } & & & & \\ \text { 佐 } & \text { 古田 } & \text { 雅 } & \text { 弘 } \\ \text { 大 } & \text { 槻 } & & \text { 真 }\end{array}$

（昭和 47 年 7 月 29 日受付）

Radioimmunoassay による血中 TSH 値の測定結果につき検討した，健常青壮年では測定感度以下 $(<1.7 \mu \mathrm{U} / \mathrm{ml}) \sim 3.6 \mu \mathrm{U} / \mathrm{ml}$ で, $2 / 3$ の例では測定感度以下であつた. 高令者では $<1.7 \sim 8.9 \mu \mathrm{U} / \mathrm{ml}$ で あり, 測定感度以下を示したものは17例中 5 例だけであつた. 未治療の甲状腺機能充進症では大多数の 例で測定感度以下であつたが，一部に detectable な例もあつた。原発性甲状腺機能低下症では 6.6〜 $1155 \mu \mathrm{U} / \mathrm{ml}$ の間に分布した. 下垂体嫌色素腺腫, 頭蓋咽頭腫, 及び肢端肥大症では健常人と殆んど変 らなかつたが, 尿崩症では感度以下の例が健常人に比べて少なかつた. 単純性甲状腺腫の半数の例は健 常人の上限よりやや高い值を示した。

\section{は じめに}

近年 radioimmunoassay の開発により比較的微量の血中 TSH の測定が可能になり，てれを利用して種 々の知見が従られつつあるが，特に健常人，及び各種甲状腺疾患々者に於ける基礎状態，即ち非刺激時の血 中 TSH 值については相当多くの報告があり各疾患毎の大まかな增堿の傾向についてはほぼ一致した見解が 得られている.しかしそれぞれの報告を詳細にみると健常人の値についても相当な違いがあり，更に各種疾 患々者に於ける測定値及びそれぞれの值と正常値との重なり合いの程度についても必ずしも一定していない． 且つ, 研究の性質上, 可成り多くの疾患単位について検討される必要があり, 個々の疾患単位について相当 数の検討がのぞまれる.

我々も約 2 年前から radioimmunoassay により血中 TSH の測定を行ない，その分泌動態に関すり研究 を行なつて来た。 ての間研究の重点を合成 TRF (Thyrotropin Releasing Factor) 投与後の血中 TSH の

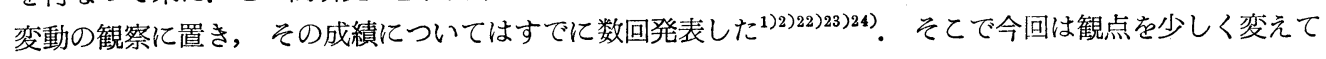
健常人及び各種内分泌疾患々者の基礎状態に於ける血中 TSH 值を中心に検討した結果について報告する.

\section{測定方法及び観察対象}

\section{1 血中 TSH 濃度の測定}

血中 TSH 濃度の測定は二抗体法による radioimmunoassay によつた。 
標識用ヒト TSH，及び抗ヒトTSH ウサギ血清はいづれも米国 National Institutes of Health より提 供されたものを用い標識 TSH としては Human Thyrotropin Research Standard A を用いた。

測定法の詳細については既に報告した ${ }^{3)}$ ので省略するが，その後判明した次の成績を補足しておきたい，

(1) 血漿の非特異的な反応により測定值が影響される事をさけるために，既報乃の如く我々は測定に際し assay system 飞 TSH を含有していないと思はれる血漿を sample と同量添加している. 即ち「重症の下 垂体性甲状腺機能低下症患者の血中には TSH が含有されていない」と云う想定の下に最初にまず本症患 者の 1 例から採取した血漿を使用し，その後は前の測定で TSH が検出されなかつた本症患者，または甲 状腺機能六進症患者の血漿を（念のため TRF に反応しない事も確かめた上で）累代的にプールして使用し た.

ての様な血漿（以下 “TSH（一）血漿” と云う）を添加して作製した標準曲線と，同時に作製した血墏を 添加しない標準曲線を比べると，入江らが成長ホルモンの radioimmunoassay で怨めている25)ように，両 者の関係は様々であつたが，0.3mlの添加では殆んどの場合前者の方が全体にやや低い bound \% を示し下 方にずれた。即ち37回の比較で，両曲線がほぽ一致したととが 3 回，“TSH (-) 血漿”を添加した曲線の 方が上方に位置したととが 1 回あつたが，他は全て “TSH（一）血槳”を添加した曲線の方が下方に位置 した. Fig. 1 はその1例を示したものである.

Fig. 1. Effect of plasma on standard curve

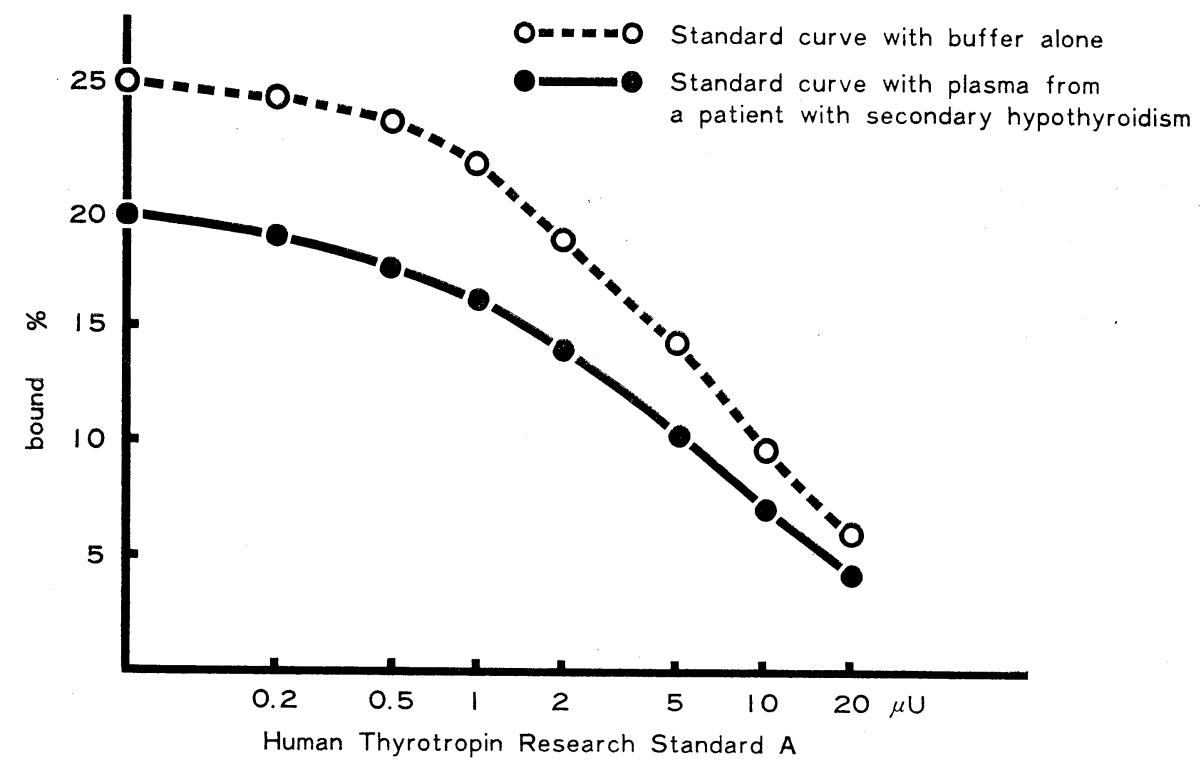

（2）“TSH（一）血漿” の代りに同量の同一患者の血清を使用して同時に標準曲線を作製し比較したとこ ろ両曲線はほぼ一致した．しかし同量のウシ血清を添加した標準曲線は下方にづれた。

尚我々の方法による測定感度は通常 1 tube 当り $0.5 \mu \mathrm{U}$ であつた. 我々は測定值が著しく高いてとが予 想される場合を除いて，1 tube に $0.3 \mathrm{ml}$ の被検血漿を加えているので，ての值を sample $1 \mathrm{ml}$ 当りに換 算すると約 $1.7 \mu \mathrm{U}$ になる。

\section{2 観察対象}

観察対象は健常人53例，各種内分泌疾患々者189例であり，その主な内訳けは Table 1 の通りである. 採血は原則として朝食前, 一部朝食から屋食迄の間にいづれも充分安静にさせた後行なつた。 
日 本内分泌学 会雑 誌

Table 1. Result of plasma TSH assay in normal subjects and patients with various endocrine disorders.

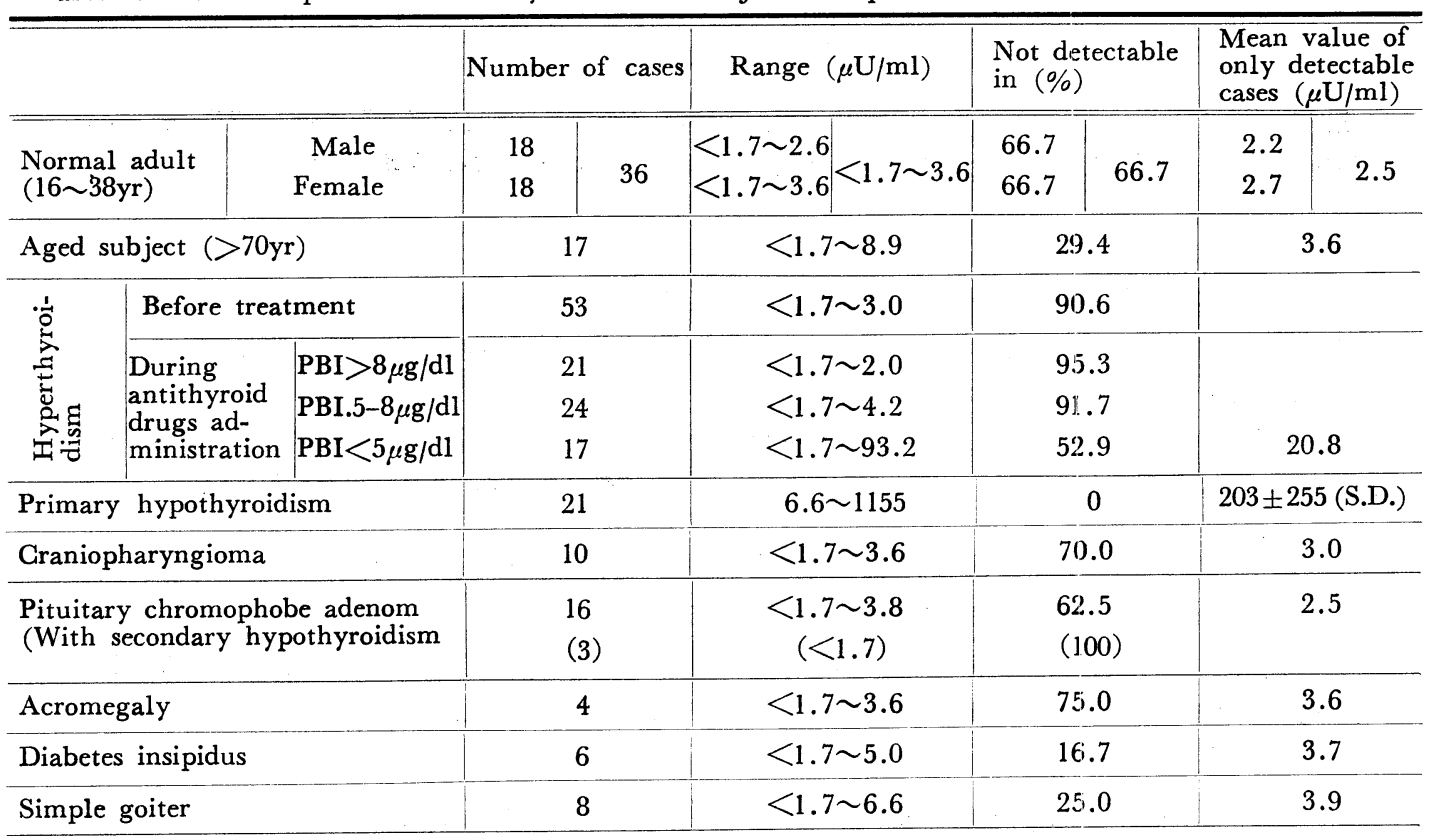

Fig. 2. Scattergram of plasma TSH levels in normal subjects and patients with various endocrine disorders.

(TSH $\mu \mathrm{U} / \mathrm{ml})$

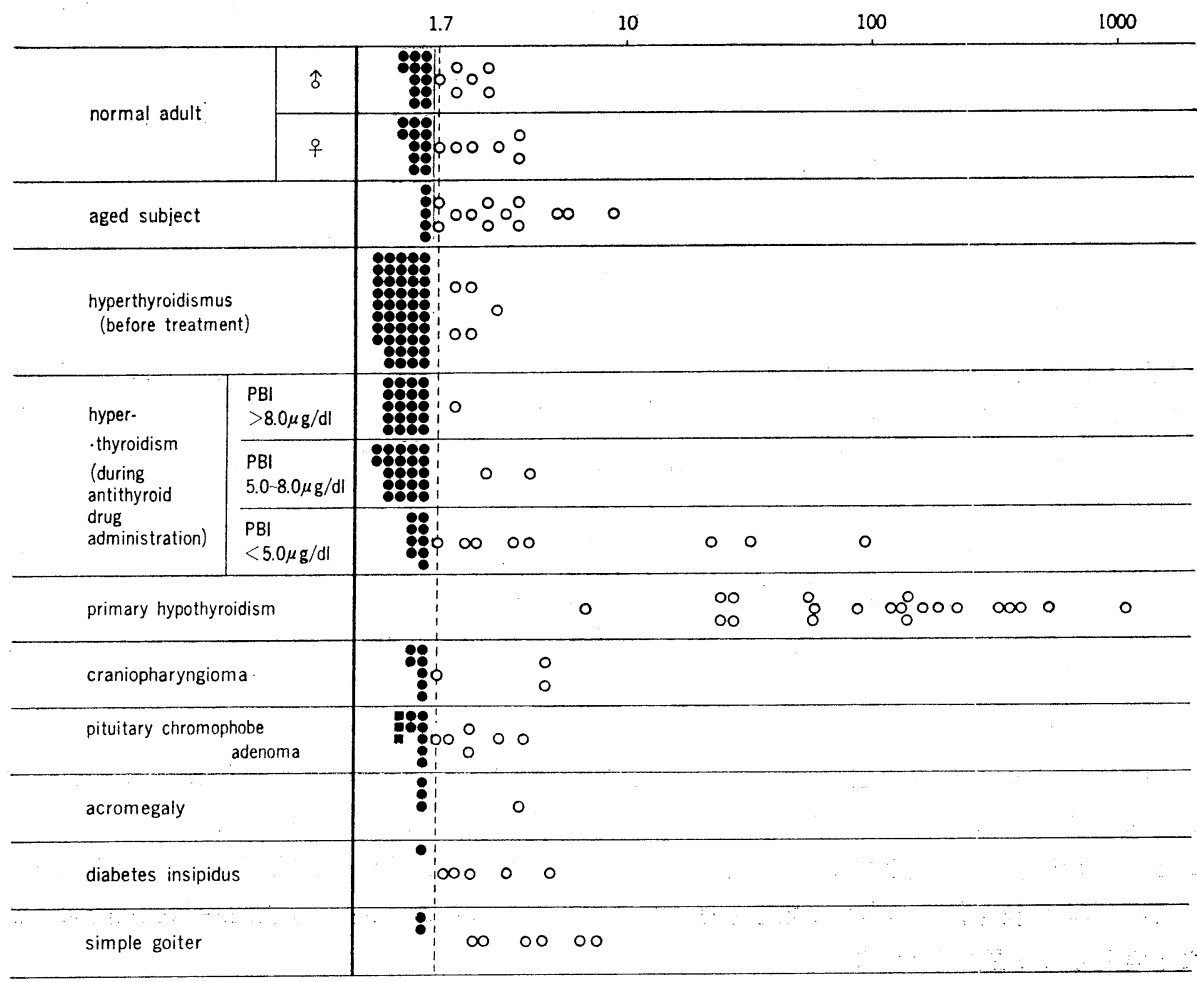

A $\mathbf{\Delta}$.....undetectable value.

D...............patient with secondary hypothyroidismus

第 48 巻 第 8 号 


\section{観 察 結 果}

観察結果は Table 1 及び Fig. 2 の通りである. Table 1 亿於ては各対象毎の測定值の分布範囲, 及び 測定感度以下の症例の占める割合の他に，比較の便のために測定可能例のみの平均值も示した。

1 健常人

(1) 青壮年群

共に16才から38才迄の健常な男女各18人ではいずれも2/3のものが測定感度以下の低值を示した。残り $1 / 3$ の平均值は女性の方がやや高く, 上限も男性 $2.6 \mu \mathrm{U} / \mathrm{ml}$ に対して, 女性 $3.6 \mu \mathrm{U} / \mathrm{ml}$ であつた。

(2) 高令者群

70 才以上の高令者群では $<1.7 \mu \mathrm{U} / \mathrm{ml}$ から $8.9 \mu \mathrm{U} / \mathrm{ml}$ までの值を示し，その上限は青壮年に比べて相当 高かつた。 又測定感度以下の例の占める割合も約 $30 \%$ で青壮年群に比べて明らかに低率であつた。

\section{2 甲状腺機能六進症}

未治療の甲状腺機能立進症患者では大多数の例, 即ち53例中48例で測定感度以下の低值であつたが, 残り の 5 例では detectable であり, $3.0 \mu \mathrm{U} / \mathrm{ml}$ までの值を示した.

この 5 例の理学的所見及び検査成績は Table 2 の通りである．表に示す様に全例に共通した特獎的な所 見は見られなかつた。 しかし 5 例中 4 例が男性であり, 男性に多い傾向が見られた.

Table 2. Symptoms and sings of the hyperthyroidal patients which had detectable plsma TSH values.

\begin{tabular}{c|c|c|c|c|c|c|c|c|c}
\hline \hline & Age & Sex & $\begin{array}{c}\text { Plsma TSH } \\
(\mu \mathrm{U} / \mathrm{ml})\end{array}$ & $\begin{array}{c}\text { BMR } \\
(\%)\end{array}$ & $\begin{array}{c}\text { PBI } \\
(\mu \mathrm{g} / \mathrm{dl})\end{array}$ & $\begin{array}{c}\mathrm{T}_{3} \mathrm{RSU} \\
(\%)\end{array}$ & LATS & Struma & Exophthalmos \\
\hline \hline 1 & 30 & $\mathrm{M}$ & 2.0 & +64 & 14.4 & 43.4 & & III & + \\
2 & 49 & $\mathrm{~F}$ & 2.0 & +60 & & 46.6 & $(+)$ & II & + \\
3 & 35 & $\mathrm{M}$ & 2.3 & +32 & 11.0 & 48.0 & $(-)$ & III & + \\
4 & 39 & $\mathrm{M}$ & 2.3 & +43 & 15.4 & 53.9 & & III & - \\
5 & 29 & $\mathrm{M}$ & 3.0 & +22 & & 49.9 & & II & - \\
\hline
\end{tabular}

次に抗甲状腺剂投与中の患者を PBI 值により 3 群に分けて観察した所, PBI $8.0 \mu \mathrm{g} / \mathrm{dl}$ 以上，及び PBI 5.0 8.0 $\mu \mathrm{g} / \mathrm{dl}$ の 2 群に於ては殆んどの例で TSH 值が測定感度以下であつたが, PBI 5.0 $\mu \mathrm{g} / \mathrm{dl}$ 以下の群に 於ては 17 例中 8 例で測定可能であり, 中には $93.2,37.7$ 及び $21.5 \mu \mathrm{U} / \mathrm{ml}$ と相当な高值を示す例もあつた.

\section{3 原発性甲状腺機能低下症}

未治療の原発性甲状腺機能低下症患者 21 例では血中 TSH 值は $6.6 \mu \mathrm{U} / \mathrm{ml}$ から $1155 \mu \mathrm{U} / \mathrm{ml}$ までの広い 範囲に分布し，殆んどの症例で健常人に比べ著るしく高い值を示した。

また本症に於て血中 TSH 值と血清 PBI 值及び ${ }^{131} \mathrm{I}_{-} \mathrm{T}_{3}$ resin sponge uptake 值との間に有意の相関々 係は認められなかつた。

\section{4 間脳下垂体疾患}

頭蓋咽頭腫，下垂体嫌色素腺腫，及び肢端肥大症患者の血中 TSH 值は健常人と殆んど変らなかつた。 しかし尿崩症では測定感度以下の例が健常人に比べて少なく 6 例中 1 例のみであつた.

下垂体嫝色素腺腫で最小測定感度以下を示した 10 例のうち 3 例は臨床的に定型的な甲状腺機能低下症状を 呈し，かつ TRF 投与後の TSH の増量も見られなかつた． 即ちての 3 例は続発性甲状腺機能低下症を合 併したと考えられる症例であつた。

\section{5 単純性甲状腺腫}




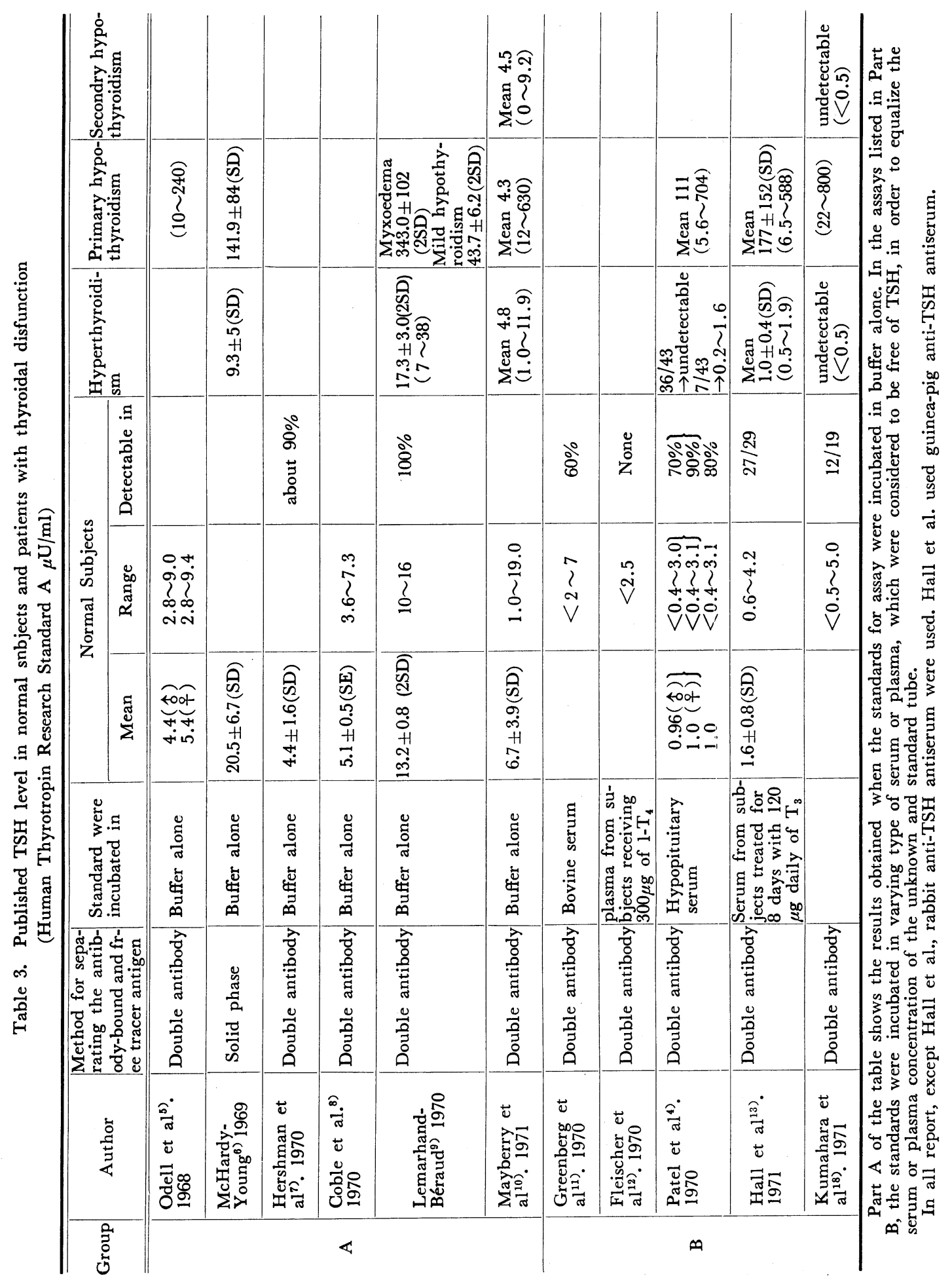


今回の測定の対象としては七条氏法で 3 度の大きさの桷漫性で比較的軟らかく表面平滑な甲状腺腫を有す るものを選んだ. 全例女性であり, 年令は18才から 24 才迄のものであつた.

本症患者 8 例の測定值は < $1.7 \sim 6.6 \mu \mathrm{U} / \mathrm{ml}$ であり，てのうち測定感度以下のものは 2 例のみで，半数の 4 例では健常人の上限より高值であつた。

\section{6 その他の疾患}

以上の他，例数が少いので Table 1, 及び Fig. 2 には示さなかつたが，甲状腺癌の 2 例の血中 TSH 值 は共に $1.7 \mu \mathrm{U} / \mathrm{ml}$ 以下であり, 甲状腺機能異常を慧めない慢性甲状腺炎の 2 例では $<1.7 \mu \mathrm{U} / \mathrm{ml}$, 及び $13.0 \mu \mathrm{U} / \mathrm{ml}$ であつた。副腎皮質の腺腫によるクッシング症候群 3 例中 2 例で $<1.7 \mu \mathrm{U} / \mathrm{ml}$ であつたが， 1 例では $2.3 \mu \mathrm{U} / \mathrm{ml}$ の值を認めた。 また神経性食思不振症 2 例の測定值は $<1.7 \mu \mathrm{U} / \mathrm{ml}$, 及び $2.6 \mu \mathrm{U} / \mathrm{mal}$ であ つた.

考按

\section{1. 健常人の血中 TSH 值について}

Radioimmuuoassay による健常人の血中 TSH 值については多くの報告があるが，参考のため我々と同 様のヒト TSH を標識用 TSH として使用し, Human Thyrotropin Research Standard A を standard とした報告の一部を Table 3 亿示した，ての表は Patel ら4)の記載した表を基に（但し我々か源著を参照 し従なかつたもの，及び原著を誤つて引用していると思はれるものは除いた）更に追加，加筆して作製し たものである. 表の如く同じ standard を用いても正常値は報告者により相当異つている， radioimmunoassay 亿於て測定法や測定機関が異なれば同一の sample の測定值が相当異なるてとがインスリン及び成長 ホルモンの測定で認められて居り ${ }^{15)}$ ，TSH についても同様のととが想像される．従つて報告者によつて正 常値がこのように異なるのは，人種差，地域差等，測定対象の違いによることも考えられるが，測定法の違 いが最も大きな原因になつていると思はれる。

Table 3 で，一般的にはA群，即ち standard を緩衝液のみで incubate したとする報告の方が，B群， 即ちTSH を含有しないと推定される血清またに血漿を添加したとする報告よりも高い值を示す傾向が見ら れる。しかし同一群内での報告者毎の差も相当大きい，いわゆる B-F 分離法の違いによる差異についてみ ると，固相法による McHardy-Young の值が二抗体法による他の值より高い，又表には示さなかつたが二 抗体法, エタノール・食塩法, 及び沪紙電気泳動法の三者では大差を認めないととが Odell ら ${ }^{17)}$ とつて報 告されている。

測定感度の違い，測定対照の年令構成の違い (Table 3 の報告では一部を除き対象の年令が示されて居ら ず，高令者を含むか否か不明である．）等の問題はあるが，一応我々の青壮年群の測定值を Table 3 の報

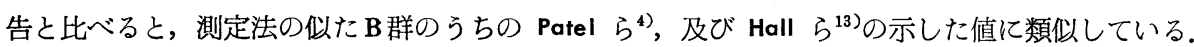

健常人の血中 TSH 值に男女差が有るか不かについて記載した論文は比較的少ないが，Mayberry ら ${ }^{10)}$ は これを認めなかつたとしている，又 Odell ら ${ }^{5)}$ の報告では Table 3 の如く range では大差が認められない が平均值では女性群でやや高い值が示されている，我々も前述の如く detectable なもののみの比較では女 性群の平均值がやや高いてとを認めたが，男女共 $2 / 3$ の例で感度以下の低值を示しているので，ての成績か らはつきりした男女差があるとは断定出来ないと思う。

次に我々は高令者群で青壮年群に比へて高い值を示す例の多いととを認めたが，同様の成績は Mayberry $ら^{10)}$ ，及び Lemarchand-Béraud $ら^{14)}$ によても得られている。乙の結果は高令者では甲状腺自身の潜在的 な機能低下を有しながら，TSH の増加で機能が維持されているものが青壮年に比べて多い可能性のあるて とを示唆しているように思はれる.しかしての関係を正確に知るためには更に血中トリヨードサイロニン量, サイロキシン結合蛋白量, 遊離甲状腺ホルモン量を含めた検討と共に高令者対象を増加しての検討も必要で あると考える。

\section{2. 甲状腺機能六進疾患者の血中 TSH 值について}


未治療の甲状腺機能亢進症患者の血中 TSH 值について Lemarhand-Béraud 㚢標識ウシ TSH 及び抗ウシ

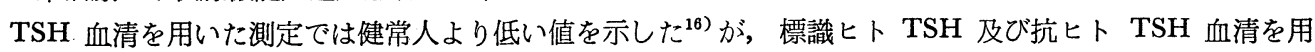
いた測定では正常またはやや高い值を示した9) と報告している．しかし他の多くの報告では低值を示すてと が一致して認められている：ただその内容は報告により若干異り，全例測定感度以下であつたとするもの (Odell $~^{17)}$, 熊原 ${ }^{18)}$, Hershman $5^{199}$ ) から測定可能域内での健常人との重なり合いを多少とも認めたと するもの (Utiger ${ }^{21)}$ ，Maybery $5^{10)}$, Patel $ら^{4)}$, Hall $\left.{ }^{13)}\right)$ まで種々である. 我々の測定した53例では前述 の如く大部分のものが感度以下の低值を示したかが 5 例では測定可能であつた。

Patel ら ${ }^{4)}$ は健常人の $80 \%$ \%か測定可能な測定法で未治療の甲状腺機能六進症患者 43 例中 7 例に於て detectable な值を認め，乙れは血清の非特異的な沈降反応の影響によるのではないかと考按している．しかし我

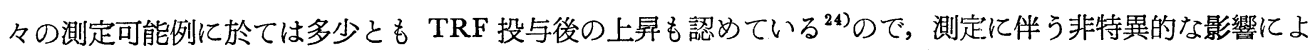
ると云うよりは，やはり未治療の甲状腺機能元進症患者の一部には TSH level が余り低下しないものが実 際に存在すると解したい.

未治療の甲状腺機能立進症患者の大多数例に於て血中 TSH 值が感度以下を示した事は血中甲状腺ホルモ ンの増加に伴う negative feed back による現象として理解しやすい. しかし TSH 值が detectable であ つた一部の症例については前述の如く他に共通した特徵を見出すてとが出来なかつたので，現在の所いかな る機序によるかは不明であると云はざるを得ない，ただてのような症例が男性に多く見られた事は興味ある 結果である.

治療により甲状腺機能の改善された患者は治療前の患者に比べ高い「SH 值を示すととが一般に認められ ているが(10)16) 18)21)，我々も前述のでとく抗甲状腺投与中の患者に於ける観察で， PBI 值か $5 \mu \mathrm{g} / \mathrm{d} 1$ 以下の 群に於て，未治療群及び治療中で PBI 值か $5 \mu \mathrm{g} / \mathrm{d} 1$ 以上の群に比べて detectable な值を示す例が明らか に多いてとを認めた。

\section{3. 原発性甲状腺機能低下患者の血中 TSH 值について}

治療前の原発性甲状腺機能低下症患者の大多数例に於て著るしい TSH 值の上昇が見られるてとは多くの 報告で一致して認められているが(4) 6)913)16) 199)，我々の成績も例外ではなかつた，ての結果は持続した血中 甲状腺ホルモンの減少が TSH 分泌増加の非常に大きな要因であることを示して居る.

本症に於ける甲状腺機能低下の程度と TSH 值の関連に関して, Lemarhand-Béraud ${ }^{9)}$ は Table 3 のでと く重症及び軽度の 2 群の間にはつきりした TSH 值の差が認められるとした. しかし Odell ら ${ }^{17)}$ は TSH 值と PBI 值及び甲状腺 ${ }^{131}$ I 摄取率との間に相関々係は見られなかつたと報告している. 我々の成績も Odell らの報告と一致している. ての成績でトリヨードサイロニンの濃度が PBI 值と TSH 值の関係流 響を与えている可能性があるととも考えられるが，更に本症患者に於ける血中 TSH level が単に一時点の 血中甲状腺ホルモンのみによつて支配されているのではなく，他の因子によつても影響されているてとも推 定される. 他の因子として下垂体 TSH 分泌予備能の個人差, 過去の血中甲状腺ホルモン濃度の消長等が 考えられるが，との点については今後検討したい.

\section{4. 間脳下垂体疾患々者の血中 TSH 值について}

下垂体嫌色素腺腫のうち続発性甲状腺機能低下症を合併した 3 例では全例で TSH を検出出来なかつた. てれは我々の測定法が前述の如く「重症の続発性甲状腺機能低下症の血中にはTSH が含有されていない か，含有されているとしてもでく僅かである」と云う想定の下に組立てられている事から見て一応は当然の 結果の様に思はれる。しかし将来今迄の例より多くの TSH を含有し, 我々の方法によつても TSH の検 出が可能な本疾患者が発見される可能性が絶対に無いとは云い切れないと思はれる。続発性甲状腺機能低下 症患者の血中 TSH 值については我々と同様全例感度以下であつたと云う報告が多いが (Utiger ${ }^{21)}$ ，Odell $ら^{17)}$, 熊原 ${ }^{18)}$, Hershman $ら^{19)}$ )，Mayberry $ら^{10)}$ は Table 3 の様な測定值を発表している。ただ彼等の測 定法は我々の方法とやや異り buffer のみで standard を incubateしているので，ての点も測定結果が我々 も異なる原因の1つになつていると思はれる。 
以上の症例を含めて，ての領域の突患に於ける血中 TSH の検討は，TRF 投与後の変動も合はせて行な

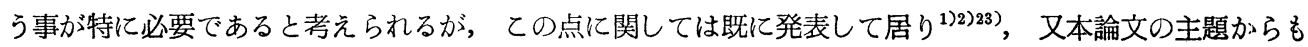
外れるので省略する．ただ尿崩症患者に於て undetectable な例が健常人に比べて低率であつた事は興味あ る成績と思はれる，我々の調べた範囲では本症患者に於ける TSH 值を radioimmunoassay で測定した報 告はみられない，しかし測定例数が比較的少ないので，更に例数を重ね甲状腺機能との関係についても詳細 に検討した上で結論を出したい.

\section{5. 単純性甲状腺腫患者の血中 TSH 值について}

我々は単純性甲状腺腫患者の半数例で健常人群の上限よりやや高い TSH 值を示すととを認めたが，ての 成績は少くとも本症の一部では甲状腺の肥大に TSH が関与している事を示しているものも思はれる. 本症 に於ける TSH 值に関しては熊原ら ${ }^{18)}$ 我々とよく似た成績を発表しているが，Lemarchand-Béraud $~^{16)}$ は 健常人に比へ僅かに高い值を示したが有意ではなかつたとし, 更に Hall ら ${ }^{13)}$ は正常範囲であつたと報告し ている，単純性甲状腺腫は種々の原因により発病すると云はれているので，報告者毎に測定対象が異なつて いる可能性もあり，てれが測定成績に相違が出来る原因の一つになつているのかも知れない.

\section{結語}

Human Thyrotropin Research Standard A standard として使用して，二抗体法による radicimmunoassay により健常人及び各種内分泌疾患々者の基礎状態に於ける血中 $\Gamma S H$ 值を測定し，次の様な結果 を得た。

1）共に16才から38才迄の健常な男女各18人の測定值は夫々 $<1.7 \sim 2.6 \mu \mathrm{U} / \mathrm{ml}$, 及び $<1.7 \sim 3.6 \mu \mathrm{U} / \mathrm{ml}$ で あり,いずれも $2 / 3$ の例で測定感度以下であつた。

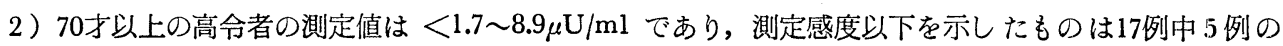
みであつた。

3 ）未治療の甲状腺機能六進症患者では殆んぞの例で測定感度以下の低值を示したが，一部には（53例中 5 例） detectable な值を示すものもあつた，抗甲状腺剤で治療中の患者のうち血清 PBI 值が $5.0 \mu \mathrm{g} / \mathrm{dl}$ 以 上の群ではやはり殆んどの例で測定不能であつたが, 血清 PBI 值が $5.0 \mu \mathrm{g} / \mathrm{dl}$ 以下の群では約半数の例で 測定可能であつた.

4 ）原発性甲状腺機能低下症患者の TSH 値は $6.6 \mu \mathrm{U} / \mathrm{ml}$ から $1155 \mu \mathrm{U} / \mathrm{ml}$ までの広い範囲に分布した.

5 ）続発性甲状腺機能低下症を合併した下垂体嫌色素腺腫の 3 例ではいづれも測定感度以下であつた。

6 ）その他の下垂体嫌色素腺腫, 頭蓋咽頭腫, 及び肢端肥大症では健常人と大差がなかつた.しかし尿崩 症では測定感度以下を示した例が健常人に比べて少なく 6 例中 1 例のみてあつた.

7 ) 単純性甲状腺腫 8 例の測定值は $<1.7 \sim 6.6 \mu \mathrm{U} / \mathrm{ml}$ であり，てのうち測定感度以下のものは 2 例のみ で, 半数の 4 例では健常人の上限より高値であつた.

以上の測定結果について, 従来の報告と比較しつつ測定法との関連, 及び測定值の病態生理学的意義の二 方向から若干の考按を行なつた.

\section{文献}

1) Sakoda, M., M. Otsuki, N. Hiroshige, K. Kanao, A. Yagi, and M. Honda : Endocrinol. Japon, 17 :541, (1970). 2) 大柣 真 : 日内泌誌, $47: 301,(1971)$.

3）弘重尚久，金尾㸃右，八 木秋子, 本田 稔, 佐古田雅弘, 大槻 真: ホルモンと臨床, $19: 299$, (1971). 4) Patel, Y.C., H.G. Burger, and B. Hudson : J. Clin. Endocr. 33 : 768, (1971). 5) Odell, W.D., L. Vanslager, and R.L. Bates : Radioisotopes in Medicine : In Vitro Studies, U.S. Atomic Energy Commission, Sereis 13, p. 185 (1968). $\quad$ 6) McHardy-Young, S. and J.P. Kriss : J. Nucl. Med., $10: 356$, (1969). 7) Hershman, J.M., D.G. Read, A.L. Baily, V.D. Norman, and T.B. Gibson : J. Glin. Endocr., 30 : 
430, (1970).

8) Coble, Y.D., and P.O. Kohler : J. Glin. Endocr. 31 : 220, (1970).

9)

Lemarchand-Béraud, T. : Acta Endocr. 64 : 610, (1970).

10) Mayberry, W.E., H. Gharb, J.M.

Bilstad, and G.W. Sizemore : Ann. Intern. Med., $74: 471$, (1971). 11 ) Greenberg, A.H., P.

Gzernichow, W. Shelley, T. Winship, and R.M. Blizzard : J. Glin. Endocr. 30 : 293, (1970).

Fleischer, N., R. Burgus, W. Vale, T. Dunn, and R. Guillemin : J. Clin. Endocr., 31 : 109, (1970). 13) Hall, R., J. Amos, and B.J. Ormston : Brit. Med. J., $1: 582$, (1971).

14) LemarchandBéraud, T., and A. Vannotti : Acta Endocr., $60: 315$, (1969). 15) 鎮目和夫 : 第 8 回ラジオイ ンムノアッセイ研究会 (於神戸), (1971).

16) Lemarchand-Béraud,T., B.R. Scazziga, and A. Vannotti, : Acta Endocr., 62 : 593, (1969).

17) Odell, W.D., J.F. Wilber, and R.D. Utiger :

Recent Prog. Horme. Res., 23 : 47, (1967).

18）熊原雄一, 福地 稳, 并上 雅, 中西 宏: 日 本臨床, $39: 496,(1971)$.

19) Hershmnn, J.M. and Pittman, J.A. : Ann. Intern. Med. 74 : 481, (1971). 20）阿部 蒸, 斉藤史郎, 田中孝司, 吉田尚義, 尾形悦郎, 中村栄一, 清水直容, 矢 内原 昇, 戸川 潔：内科, $29: 735$, (1972). $\quad 21)$ Utiger, R.D. : J. Glin. Invest., 44: 1277, (1965). 22）佐古田雅弘, 大柣 真, 深津泰良, 馬場茂明, 弘重尚久：日内泌誌，47：1046, (1972). 23）佐古田雅弘, 大柣 真, 森頴太郎, 馬場茂明, 弘重尚久: 日内泌誌, $48: 90$, (1972). 24）佐古田雅弘, 大譛 真, 日下孝明, 馬場茂明：日内泌誌, $48: 167$, (1972). 25）入江 実, 対馬敏夫 : 最新医学, $26: 1059$, (1971). 